\title{
Review
}

\section{Images of the Prophet Muhammad: some new books on the Sira literature}

\author{
GÖRAN LARSSON \\ University of Gothenburg
}

With the publication of the 'Muhammad cartoons' in September 2005 by the Danish newspaper Jyllands-Posten and the conflicts that followed in 2006, interest has increased among both Muslims and non-Muslims in the life of the Prophet Muhammad and his biography. Because of the conflict, a growing number of Muslim writers and non-Muslim academic scholars have started to focus on the sources, the historicity, and the portrayal of the life of the Prophet.

In order to understand and evaluate the importance, place and function of the so-called Sira literature, the collective Arabic name for the literary genre that deals with the life of the Prophet Muhammad, it is first essential to have an overview of the basic sources and to understand how this specific genre has developed over the years. An excellent guide and introduction to these intriguing questions is Tarif Khalidi's monograph, Images of Muhammad: Narratives of the Prophet in Islam across the Centuries. For example, contrary to Tariq Ramadan's inside perspective as presented in The Messenger: The Meanings of the Life of Muhammad, Khalidi's book offers a thorough and critical outline of the Sira genre by focusing on its internal variations and showing how it has been used by Muslim writers for different purposes. Khalidi stresses that, even though all Muslim writers more or less use the same sources (i.e. the texts produced by Ibn Ishāà, al-Balādhurī, al-Ṭabarī and Ibn Sa'd, all dated to the 9th and 10th centuries), the compilers of the biography of Muhammad have collected, edited and selected passages for different reasons. To understand this process, it is vital to stress that biography can be written with many purposes and aims. Khalidi summarize four principal uses or aims of biography: 
to provide inspiring examples to be imitated to celebrate famous men and women of a particular nation to exalt the self-image of a particular professor or group to show how a particular life took on a meaningful shape (bildungsroman) (Khalidi 2009: 7).

Both Khalidi and other books mentioned in this review essay show that the four categories are all represented in the historical and contemporary Sira literature. With the help of the classical sources (i.e. Ibn Ishāa, al-Balādhurī, al-Tabarī and Ibn Sa'd), it is possible to edit and describe aspects of the life of the Prophet to achieve a particular purpose. The Prophet can, for example, be presented as an 'ordinary, frail, fallible human being', an image that is easy for the general reader to grasp, and more importantly an example that can be imitated and followed. As in Ramadan's book, mentioned earlier, Muhammad is above all an ethical and normative example for Muslims. However, Khalidi demonstrates convincingly that the Prophet also can be dressed up in nationalist guise. Within this tradition, he is used as a postcolonial fighter who is battling with the colonial power and 'Western' values. This 'use' of the Prophet is, for example, present in the Egyptian writer Husayn Haykal's (d. 1956) popular biography entitled Hayāt Muhammad (The Life of Muhammad). In contrasted to this humanist approach, Khalidi demonstrates that the life of the Prophet can also be presented as a miracle, a tendency of particular importance among the mystics of Islam. Muhammad's position and his importance for popular beliefs and devotion should not be underestimated in any assessment of the Sir $r$ literature. But the life of Muhammad can also be used for 'solving' theological and political differences between Shia and Sunni Muslims. Depending on which parts of the Sira a particular author quotes, it is possible to argue that Muhammad is in favour of both the Sunni and the Shia branches of Islam. This is an illustration and reminder that the history of early Islam is not neutral or unimportant; on the contrary, the understanding and use of history is of vital importance among contemporary Muslims. How different Muslim groups use and construe history has little to do with historical source criticism, however, or to use the famous quote of the German historian Leopold von Ranke (d. 1886) 'Wie es eigentlich gewesen'. Those readers who are able to read Swedish will find a similar approach to the history of Muhammad in Jan Hjärpe's book Bilden av profeten: Berättelserna om Muhammad och deras function för och nu (The Image of the Prophet: Stories of Muhammad and their 
function, now and then). Like Khalidi, Hjärpe is mainly interested in how the history of Muhammad and the early Muslim community has been construed and how it functions within both Muslim and non-Muslim milieux.

If the advantage of Khalidi's and Hjärpe's books lies in their thorough discussion of how various Muslims have used and construed the history of Muhammad, the reader will find both similarities and differences in Jonathan E. Brockopp's edited volume, The Cambridge Companion to Muhammad. This volume consists of fourteen chapters dealing, among other things, with source criticism, historical and contemporary Sirra literature, and local examples of how the life of Muhammad has been connected with piety, ritual and political aspirations. Resembling the conclusions found in Khalidi's book, Uri Rubin and other authors in this volume conclude and argue convincingly that the narrative or story of the life of Muhammad must be read in relation to earlier prophecies found in the Near East. For the early Sira compilers, it was important to present and establish that Muhammad should be viewed as a prophet who was similar to, but also different from earlier prophecies and revelations. The continuity with earlier traditions and religions is a theme found both in the Koran and the Sira literature. Muhammad is a messenger like the earlier prophets, but according to Muslim belief he is the last prophet. Consequently, the Koran is the final and true revelation, as compared to earlier revelations that have become corrupted by mankind.

In his chapter 'European accounts of Muhammad's life', John V. Tolan gives a detailed historical exposé of the Western images of Muhammad from the medieval and early modern period (published in Brockopp). Even though there is not just one but several images of Muhammad among all non-Muslim Western writers, Tolan illustrates clearly that many Westerners have portrayed Muhammad in a negative and polemical light, for example, as a fake prophet, a heretic, a hedonist etc. Although the importance of these historical images should not be over-estimated, it is evident that the polemical and offensive approach resembles the discussion that followed the publication of the Muhammad cartoons in Denmark in 2005. The political turmoil and global crisis that followed this publication is analysed and presented in great detail in Jytte Klausen's The Cartoons That Shook the World. Without going into detail regarding this rich and complex study, it is important to stress that the Jyllands-Posten publications clashed with how Muslims in general view the life of the Prophet Muhammad. Instead of presenting him in a positive manner as devout, the Danish cartoonists decided to portray him as a potential terrorist and a serious threat to the Western world. In order to understand all aspects of this conflict, it is crucial 
to have some idea of the role and function of the Prophet for Muslims. From this point of view, the study of the Sirra literature has developed from being a topic of interest mainly for philologists and medieval historians, into being required study for all students and academics who want to understand Islam and Muslims in both history and the contemporary period, no matter what their discipline or interests.

Thus it seems that the negative and destructive forces that were released with the publication of the Jyllands-Posten cartoons have had the side effect of fuelling a growing interest in the study of the life of Muhammad and the early history of Islam. In my view, all the books presented in this short literature review have great potential to help us to think more critically about the relationship between history and contemporary studies and the formation of early Islam.

Bibliography

Brockopp, Jonathan E. (ed.)

2010 The Cambridge Companion to Muhammad. Cambridge: Cambridge University Press.

\section{Hjärpe, Jan}

2011 Bilden av profeten: Berättelserna om Muhammed och deras function förr och $n u$. Stockholm: Leopard Förlag.

\section{Khalidi, Tarif}

2009 Images of Muhammad: Narratives of the Prophet in Islam across the Centuries. New York and London: Doubleday.

\section{Klausen, Jytte}

2009 The Cartoons That Shook the World. New Haven and London: Yale University Press.

\section{Ramadan, Tariq}

2007 The Messenger: The Meanings of the Life of Muhammad. London and New York: Penguin Books. 